\title{
Experiment of Removing Traces of Phosphorus in Water Using Bottom Sludge of Ise-Bay
}

\author{
Yukimasa Takemoto ${ }^{1}$, Masaaki Takahashi ${ }^{1}$, Kati Nabin ${ }^{1}$, Adhikari Jayaram ${ }^{1}$, Maki Ooyagi ${ }^{1}$, Shrestha Rashim \\ Bahadur $^{1}$, Eiji Yuki ${ }^{2}$ and Takanori Terazawa ${ }^{3}$ \\ 1. Yokkaichi University, Research Laboratory on Environmental Technology, Kayo-cho 1200, Yokkaichi, Mie 512- 8512, Japan \\ 2. Mie Chuo Kaihatsu Co., Ltd, Hachiya 4713, Yono, Iga, Mie 518-1152, Japan \\ 3. Mie prefectural Environmental Conservation Agency, Ueno 3258, Kawage, Tsu, Mie 510-0304, Japan
}

\begin{abstract}
Large amounts of sludge has accumulated in the Inner Bay, which is one factor of environmental deterioration. We found that this sludge has an effect of absorbing low concentrations of phosphorus in water. For the purpose of development of water treatment agents and effective utilization of the sludge, phosphorus removal performance was investigated using wet sludge collected in Ise-Bay. A small amount of sludge was added to the test water having a phosphorus concentration of about 1 2 mg/L, and the phosphorus concentration of the filtrate after stirring and filtration was measured. Depending on the sludge conditions, it showed $30 \%$ to $80 \%$ of phosphorus removal performance. We investigated the relationship between the physical properties of the sludge and the removal performance.
\end{abstract}

Key words: Bay sediment, phosphorus removal, water treatment.

\section{Introduction}

A large amount of sludge has accumulated on the seabed of many closed waters (Inner Bay) including Ise-Bay [1], which is one cause of the environmental deterioration [2]. To improve the environment, dredging of this sludge has been carried out, and some part of the dredged sludge is used for landfilling of harbors and coastal tideland [3]. However, its application is limited, and in many cases, it becomes a difficult waste, and finding the recycle method is required $[4,5]$.

On the other hand, the sludge at the bottom of the sea usually consists of clay, but contains a large amount of salt, which hinders the effective use. Clay is a widely distributed resource on the earth, but high quality clay tends to be deficient, and in Japan, much of it is imported from other nations. Sludge of the sea can be used as a substitute of clay or cement raw material by removing the salt component.

Corresponding author: Masaaki Takahashi, researcher, research field: environmental technology.
We found that this sludge had the absorption effect of phosphorus in water [6]. Phosphorus is a component which is difficult to remove by biological treatment, and usually treatment agent, compounds containing iron and aluminum are used [7-9], but in consideration of cost effectiveness, inexpensive removal agent is desired. Therefore, for the purpose of development of the treatment agent and effective use of sludge, the investigation of the phosphorus removal effect using sludge was carried out [10].

\section{Methods}

\subsection{Materials Used}

\subsubsection{Sludge}

We used wet sludge collected from the bottom of Ise-Bay. Properties of the sludge and its chemical composition (dried matter) are shown in Tables 1 and 2. Sludge A to F was collected on the seabed at the central part of the Ise-Bay, G1, G2 and G3 are the same sludge in Yokkaichi Port, but were reserved in an aerobic condition, and the properties of the sludge 
Table 1 Properties of sludge.

\begin{tabular}{llllllllll}
\hline Sludge & A & B & C & D & E & F & G1 & G2 & G3 \\
\hline ORP (mV) & 97 & 196 & 336 & -101 & 150 & -53 & -76 & No data & -17 \\
P removal rate (\%) & 37 & 43 & 29 & 65 & 47 & 65 & 51 & 67 & 80 \\
AVS (mg/g) & 0.20 & 0.38 & 0.07 & 0.99 & 0.20 & 0.59 & 1.47 & 0.14 & 0.11 \\
Water content (\%) & 73 & 77 & 70 & 81 & 69 & 65 & 70 & 76 & 58 \\
Heat loss on heating (\%) & 9.3 & 9.9 & 9.1 & 10.7 & 8.1 & 8.4 & 8.7 & 8.4 & 8.0 \\
\hline
\end{tabular}

Table 2 Chemical composition of sludge (dry matter of sludge G1).

\begin{tabular}{llllllllll}
\hline Element & $\mathrm{Na}_{2} \mathrm{O}$ & $\mathrm{MgO}$ & $\mathrm{Al}_{2} \mathrm{O}_{3}$ & $\mathrm{SiO}_{2}$ & $\mathrm{SO}_{3}$ & $\mathrm{Cl}$ & $\mathrm{K}_{2} \mathrm{O}$ & $\mathrm{Fe}_{2} \mathrm{O}_{3}$ & $\mathrm{Others}$ \\
\hline Composition (\%) & 1.7 & 2.4 & 10.7 & 62.8 & 1.9 & 3.5 & 3.0 & 10.3 & 3.7 \\
\hline
\end{tabular}

were changed by the difference in preservation state.

\subsubsection{Test Water}

The two types of the phosphorus-containing water used for the test are shown below.

Test ware: Sodium phosphate was dissolved in water and the phosphorus concentration was adjusted to around $1 \mathrm{mg} / \mathrm{L}$ to $2 \mathrm{mg} / \mathrm{L}$.

Contaminated water: A small amount of livestock wastewater was added to contaminated river water.

\subsection{Experiment Procedure}

Sludge (water content 70\%-80\%) was added to 100 $\mathrm{mL}$ of test water, stirred for 1-2 minutes, and filtered using a filter paper (Toyo Roshi Kaisha, ADVANTEC, $5 \mathrm{~A})$. The various components were analyzed and compared with the test water.

The analysis method is as follows.

pH: Glass electrode

EC: Platinum electrode

ORP (Oxidation and Reduction Potential): ORP electrode

Phosphorus: Ammonium molybdate colorimetric method

$\mathrm{NO}_{3}-\mathrm{N}$ (Nitrate nitrogen): UV absorption method

COD: Acid manganese method

$\mathrm{NH}_{4}$ ion: Indophenol method

Chloride ion: Silver nitrate titration method

Water content: Drying at $105^{\circ} \mathrm{C}$

Ignition loss: Heating at $650{ }^{\circ} \mathrm{C}$

AVS (Acid volatile sulfur): Detector tube kit for AVS (Gas Tec Co., Ltd.)

\section{Results and Discussion}

\subsection{Phosphorus Removal Performance}

To determine an appropriate sludge addition amount (solid-liquid ratio), $1 \mathrm{~g}$ to $10 \mathrm{~g}$ of wet sludge (sludge A) was added to $100 \mathrm{~mL}$ of the test water, and this determined the phosphorus concentration in the treated water. As the sludge addition rate increased, the phosphorus concentration in the treated water decreased (Fig. 1). Therefore, it was judged that solid-liquid ratio 1:10 which was usually adopted was appropriate, and this solid-liquid ratio was used in subsequent experiments.

Comparing the $\mathrm{PO}_{4}-\mathrm{P}$ concentration in the test water and raw test water, the phosphorus removal rate was calculated, and the removal rate differed depending on the sludge added to it. In this experiment, the removal rate reached $20 \%$ to $80 \%$. The water content of the sludge reached almost $8 \%$ to $10 \%$, however, the phosphorus removal rate differed $20 \%$ to $80 \%$ as mentioned, and also, the same trend was found in the ignition loss (Figs. 2 or 3). On the other hand, in the lower ORP value, higher removal rate was observed (Fig. 4), and also, in the higher AVS, higher removal rate was found (Fig. 5). As described above, G1, G2, G3 are the same sludge, but the AVS was different, $0.11 \mathrm{mg} / \mathrm{g}$.dry to 1.47 $\mathrm{mg} / \mathrm{g}$.dry by preservation in different aerobic state as mentioned. The apparent difference of the phosphorus removal rate was observed in the sludge G1 to G3, and also, in the relation of the ORP. This result indicates 
$\mathrm{P}(\mathrm{mg} / \mathrm{L})$

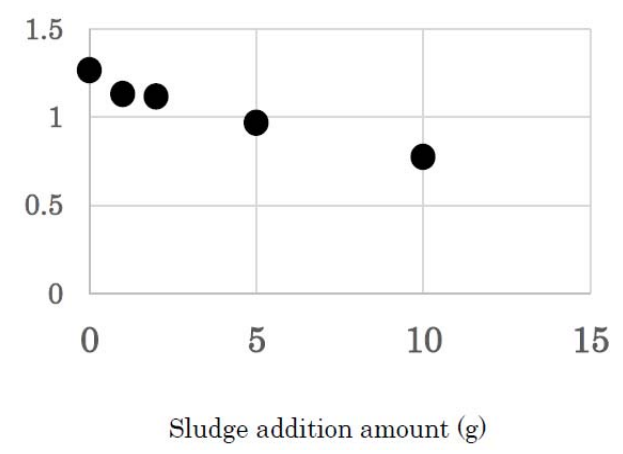

Fig. 1 Sludge addition amount and phosphorus.

Water content $(\%)$

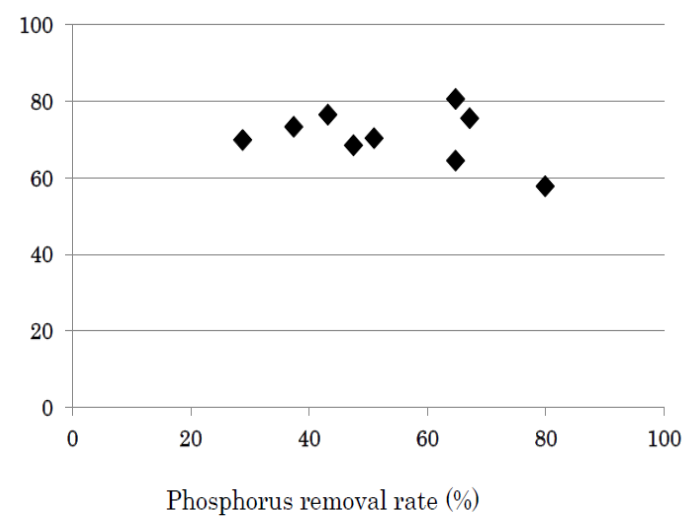

Fig. 2 Phosphorus removal rate and water content concentration of the treated water.

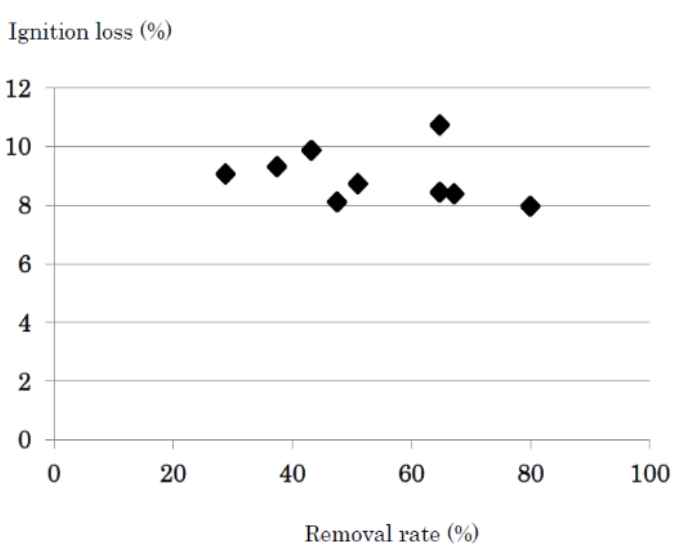

Fig. 3 Phosphorus removal rate and ignition loss.

the oxidation process is related in the removal of the phosphorus.

In most of the wastewater treatments, iron compounds are used in the phosphorus removal, in this case, $\mathrm{Fe}^{3+}$ ion forms water insoluble $\mathrm{FePO}_{4}$ by

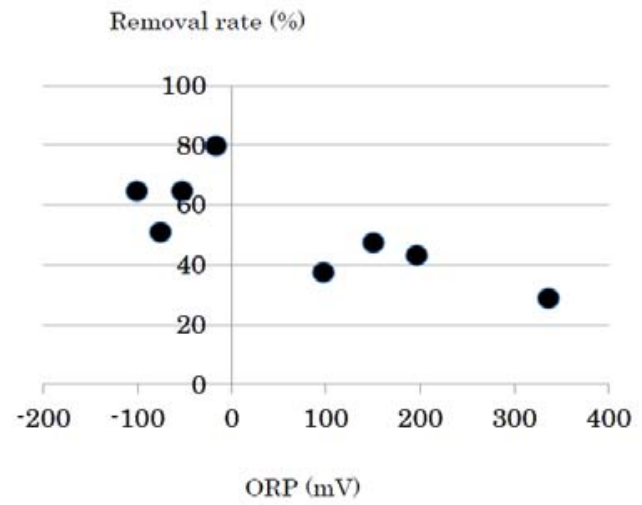

Fig. 4 Relation of the removal rate and ORP.

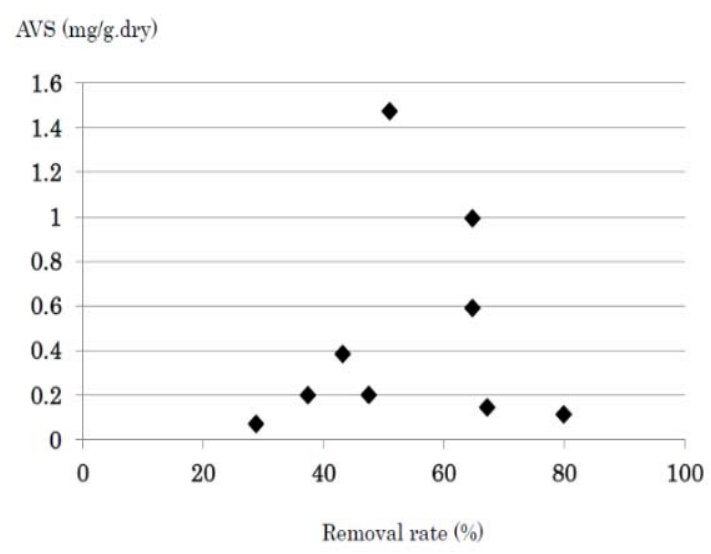

Fig. 5 Phosphorus removal rate and AVS.

oxidation of $\mathrm{Fe}^{2+}$ ion. We consider that in an anaerobic sludge, there is $\mathrm{Fe}^{2+}$ (mainly as a compound $\mathrm{FeS}$ ), and this is oxidized by stirring with test water resulting in phosphorus removal [10]. From the result, we expect a higher phosphorus removal rate will be attained by improving the oxidation processes.

\subsection{Water Treatment Test}

In order to confirm the phosphorus removal performance, and the quality of the treated water, the test was carried out using test water and polluted water. The results are shown in Table 3.

Phosphorus in the test water and the polluted water was greatly reduced by the treatment, and the removal effect was confirmed. The EC and salinity of the treated water was increased, and this is considered to be caused by the elution of salt component in the sludge. COD is increased about $10 \mathrm{mg} / \mathrm{L}$, and it is 
Table 3 Water quality of the treated water.

\begin{tabular}{llllllll}
\hline Water & $\mathrm{pH}$ & $\mathrm{EC}(\mathrm{mS} / \mathrm{cm})$ & $\mathrm{COD}(\mathrm{mg} / \mathrm{L})$ & $\mathrm{CL}(\mathrm{mg} / \mathrm{L})$ & $\begin{array}{l}\mathrm{NO}_{3}-\mathrm{N} \\
(\mathrm{mg} / \mathrm{L})\end{array}$ & $\begin{array}{l}\mathrm{PO}_{4}-\mathrm{P} \\
(\mathrm{mg} / \mathrm{L})\end{array}$ & $\begin{array}{l}\mathrm{NH}_{4}-\mathrm{N} \\
(\mathrm{mg} / \mathrm{L})\end{array}$ \\
\hline $\begin{array}{l}\text { Raw water } \\
\text { (polluted water) }\end{array}$ & 7.7 & 0.27 & 9.6 & 34 & 7.14 & 1.8 & 3.1 \\
$\begin{array}{l}\text { Treated water } \\
\text { (Polluted water) }\end{array}$ & 8 & 2 & 13.3 & 1490 & 6.55 & 0.91 & 3 \\
$\begin{array}{l}\text { Raw water } \\
\text { (test water) }\end{array}$ & 7.3 & 0.16 & 0.3 & 16 & 3.95 & 1.37 & 0 \\
$\begin{array}{l}\text { Treated water } \\
\text { (test water) }\end{array}$ & 7.9 & 2 & 7.1 & 1450 & 5.17 & 0.5 & 0.65 \\
\hline
\end{tabular}

Table 4 Property of the treated sludge.

\begin{tabular}{|c|c|c|c|c|c|}
\hline & ORP $(\mathrm{mV})$ & Water content (\%) & Ignition loss (\%) & AVS (mgS/g.dry) & CL (salinity) (\%) \\
\hline Pre-treatment mud & -81 & 69 & 8.4 & 0.68 & 3.5 \\
\hline $\begin{array}{l}\text { Treated sludge } \\
\text { (Test water) }\end{array}$ & -57 & 67 & 7.5 & 0.21 & 0.55 \\
\hline $\begin{array}{l}\text { Treated sludge } \\
\text { (Polluted water) }\end{array}$ & -54 & 69 & 7.8 & 0.29 & 0.45 \\
\hline
\end{tabular}

presumed to be due to elution of organic matter in the sludge. Contrary, no significant change in $\mathrm{pH}, \mathrm{NO}_{3}-\mathrm{N}$, and $\mathrm{NH}_{4}$ ions was observed. These results indicate the treated water can be discharged in ocean except for COD. In the case of the COD emission, emission standards (120 mg/L in Japan) should be considered. The treated sludge, no significant change of the physical state was found as water content and ignition loss. On the contrary, AVS of the treated sludge was degreased, and ORP value rose as shown in Table 4. It is considered to be the oxidation phenomenon of the sludge. Salinity of the sludge decreased significantly from $3.5 \%$ to around $0.5 \%$. The chemical composition of the sludge is similar to that of clay, the salt removed sludge may be used as a soil [11] or pottery [12] or raw material for cement [13]. However, as in the case of the cement utilization, the criteria for the salt concentration are less than $0.1 \%$ [14], therefore much improvement is needed in the washing method (adjustment of the solid-liquid ratio, washing time, etc.).

\section{Summary}

Since the bottom sludge of the sea can have the phosphorus removal performance in the water, we investigated the ability using the low concentration of the phosphorus solution. So, $20 \%$ to $80 \%$ of the phosphorus in the water can be removed. No significant change was found in the treated water in its nutrient as $\mathrm{NO}_{3}-\mathrm{N}, \mathrm{NH}_{4}-\mathrm{N}$, except for COD.

The treated sludge contained small content of the salt, and can be used for a substitute of clay material. The phosphorus removal effect is considered to be caused by the oxidation phenomenon of sludge. However, furthermore, it is necessary to improve the processing method and to find effective usage according to the characteristics of the processed sludge.

\section{Acknowledgments}

In doing this research, we would like to express our gratitude to the participants of Mie University's Faculty of Bio-resource Sciences, Yokkaichi Port Management Association (Maintenance Division) and Dr. Satoshi Chiba (Professor of Yokkaichi University, Faculty of Environment and Information Sciences) who provides the research materials. We also express our gratitude to Dr. Eric Bray (Professor of Yokkaichi University) for his advice on making the article.

\section{References}

[1] Masashi, S., Nobuyuki, S., Masayuki, M., Koji, I., Hiroshi, T., and Shinobu, I. 1982. "Heavy Metal Pollution of Bottom Sediments on Ise-Bay.” Report of Hydrographic Researches No. 17, March 379-93. (in 
Japanese)

[2] Masaaki, T., Kunihiko, S., Hideki, K., Seiji, I., and Susumu, K. 2002. "Current Status of Water Pollution in Ago-Bay.” Journal of Environmental Laboratories Association 27 (1): 51-6. (in Japanese)

[3] Masaaki, T., Hideki, K., Seiji, I., and Susumu, K. 2001. “Technology for Constructing Artificial Tidal Land with Salvaged Sludge (2) Physic-chemical Change of the Salvaged Sludge by Drying Processes.” Anural Reports of Mie Prefectural Institute of Health and Environmental Research 46 (3). (in Japanese)

[4] Masaaki, T., and Hideo, M. 1998. "Current State of Inner Bay Sludge and Direction of Effective Use." In Proceedings of the ISE-SHIMA 2rd International Oceanic Conference, 1-9. (in Japanese)

[5] Masato, H. 2006. "Trends and Future Development of Dredging Sludge Recycling Technology.” Environmental Technology 35 (6): 431-6. Accessed 25th Jan. 2019. https://www.jstage.jst.go.jp/article/jriet1972/35/6/35_6_4 31/_pdf.

[6] Hideki, K., Seiji, I., Susumu, K., Hideo, E., and Masaaki, T. 2001. "Nitrogen and Phosphorus Removal Effect of Bay Sediments." The Proceedings of 35th Anural Conference of Japan Water Association, p. 94. (in Japanese)

[7] Manual for Water and Waste Treatment by Aluminum Coagulative Agents, Asada Kagakukogyo Co., Ltd. Accessed Jan 20th 2019. https://www.jstage.jst.go.jp/article/jtappij1955/25/10/25_ 10_535/_pdf.

[8] Tetsushi, O., Phengxay, D., Takao, H., Wataru, N., and Mitsumasa, O. 2004. "The Performance of Poly-Silicate Iron Coagulant in Conventional Drinking Water
Treatment.” Water Supply Journal (Japan Water Works Association) 73 (11): 2-10.

[9] Japanese Patent, J P 2007-268338. Phosphorus Removal by Iron.

[10] Yukimasa, T., Masaaki, T., Maki, O., Shrestha, R. B., Khati, N., and Adhikari, J. 2018. "Experiment of Removing Traces of Phosphorus in Water Using Bottom Sludge of Ise-Bay." In Proceedings of the 29th Annual Conference of the Japan Society of Waste Management Expert, 223-4. (in Japanese)

[11] Dozyou Shindann, G., Hiryou-Nougyou-Bu, Soil Diagnosis Guide JA. Fertilizer Pesticide Department. Accessed Jan. 20th 2019. https://www.zennoh.or.jp/activity/hiryo_sehi/pdf/gijyutu_1 -01b.pdf\#search=\%27\%E6\%B0\%B4\%E7\%94\%B0\%E7\% B2\%98\%E5\%9C\%9F\%E5\%A1\%A9\%E5\%88\%86\%27.

[12] Toshizumi, H., Hiroshi, T., Humihiko, J., and Hideo, N. 1996. "Researches of the Road-Pavement Material Using Biwa Lake Sediment." In Proceedings of 7th annual conference of the Japan society of waste management expert, 6-17. (in Japanese)

[13] Cement Raw Materials, Accessed Jan. 20ty 2019. http://www.japan-flyash.com/pdf/fcuse04.pdf\#search=\%2 7\%Е3\%82\%BB\%Е3\%83\%A1\%Е3\%83\%B3\%Е3\%83\%8 8\%Е5\%8Е\%9F\%Е6\%96\%99\%Е3\%81\%А8\%Е3\%81\%А $\mathrm{F} \% 27$.

[14] Cement Raw Material Accept Standards, Accessed Jan. 20th 2019. http://www.meti.go.jp/policy/recycle/main/data/research/ pdf/150711-3_jilc_7.pdf\#search=\%27\%E3\%82\%BB\%E3 \%83\%A1\%Е3\%83\%B3\%Е3\%83\%88\%Е5\%8E\%9F\%Е6 \%96\%99\%Е5\%8F\%97\%Е3\%81\%91\%Е5\%85\%A5\%Е3 \%82\%8C\%Е5\%9F\%BA\%Е6\%BA\%96\%27. 